\title{
Assessing Mathematics Teachers' Knowledge in Teaching Thinking Skills
}

\author{
Zulhelmi Zulkpli, Mohini Mohamed, Abdul Halim Abdullah* \\ Faculty of Education, Universiti Teknologi Malaysia, 81310 UTM Johor Bahru, Johor, Malaysia \\ *Corresponding author: p-halim@utm.my
}

\begin{abstract}
Teaching of thinking skills, paramount in effective teaching and learning of Mathematics, requires sufficiently knowledgeable teachers for its delivery. As such, it is equally important to determine the minimum level of knowledge required of the teachers, so that, the intended tasks could be carried out successfully. Thus, this quantitative study was conducted with its aim to identify the level of teachers' knowledge in teaching thinking skills. A total of 199 Mathematics teachers were selected as the respondents in this study. The collected data was analyzed inferentially to identify the levels of teachers' knowledge in teaching thinking skills across school categories. The results obtained showed that, Mathematics teachers in primary schools had a relatively lower level of knowledge in teaching thinking skills, compared to their peers in secondary schools. This study revealed the importance of teaching thinking skills to students. Teacher must gain the mastery of thinking skills themselves, so that they would be able to deliver the related lessons effectively. Thus, Mathematics teacher should always keep improving themselves to fully master the teaching of thinking skills to the students.
\end{abstract}

Keywords: Thinking skills; teachers' knowledge; Mathematics teacher.

(C) 2017 Penerbit UTM Press. All rights reserved

\subsection{INTRODUCTION}

The education system in Malaysia has undergone quite a radical transformation that began in the 1990's, in response to changes in the global rankings. Teachers act as recipients of the information about the curriculum and learning materials gained from external resources and subsequently disseminate them to the students [1]. Teaching thinking skills in Malaysia was introduced in the teaching and learning process in 1994 [3]. The teaching of thinking skills in schools is important as it enables students to solve problems and make decisions in their daily lives, ([4] and [5]). Thinking skills are the ability to do cognitive processes, including perception, knowledge, and, creation and exploration of ideas, decision making and problem solving with the best options. ([2], [6], [7], and [19]). In addition, thinking skills could also be defined as a discipline of knowledge which could be practised and learned [8]. Generally, thinking skills could be divided into four components, namely, critical thinking, creative thinking, decision making and problem solving skills.

Teachers must equip themselves with knowledge, skills and new practices required to fulfil the objectives of teaching and learning of the 21st century [10] and they must give priority to effectively get the thinking skills across the various fields of knowledge among students. [11]. Besides, they need to be wise to cultivate students' ability to analyze, synthesize, and evaluate facts and information, to use thinking skills to solve problems and make decisions, to have personal and inter-personal communication skills and to find alternative pedagogy while applying these skills with the passage of time. ([12] and [13]). The aims of this study were to identify the levels of Mathematics teachers' knowledge in teaching thinking skills, and to ascertain the differences in these levels across school categories (primary school teachers versus secondary school teachers).

\section{Problem Statement}

The hesitation among teachers to implement teaching of thinking skills was due to the lack of knowledge and skills, and this was considered to be the most serious problem which hindered the achievement of the intended set objectives [4]. In general, teachers were not well prepared to teach thinking skills due to lack of understanding in the field of critical and creative thinking ([4] and [15]). Most of them were more inclined to emphasize on the teaching of lower order thinking skills, compared to higher-order thinking skills. According to [17], most teachers did not know how to apply thinking skills to students while some were not willing to do it. Some teachers were of the opinion that, students had to find out all the facts and concepts of a subject, before they could be encouraged to think [14]. These were some of the hindrances that prevented teachers from utilizing more promising teaching practices, such as, problem solving, decision making and inquiry skills to develop thinking skills among the students.

Thinking Skills and Knowledges

A variety of terms have been invented to describe various types of thinking, including thinking reflexively, critical thinking, creative thinking, deductive thinking, logical thinking, inductive thinking, analytical thinking and analogical thinking. The definition of thinking 
skills, adopted in this study was, the process of using the mind to search for meaning and understanding of something, to examine the possibilities of ideas or products and to make a good judgement for problem solving and decision making, reflection and metacognition of the experienced process ([18 and [19]). However, thinking skills discussed in this study only focuced on critical thinking skills, creative thinking skills, problem solving skills and decision-making skills [9] (refer figure 1).

Educators must not only have sound knowledge about the subject in their fields to promote thinking skills among students, they must also be well equipped with good pedagogical knowledge to improve students' thinking skills and general skills in the context of the subject matter [20]. [21] explained that, the dimensions of thinking skills can be summarized as the integration of the knowledge of teaching of thinking into the "knowledge of the elemental thinking". [21] further mentioned that, there were four sub-categories, which were very useful for future references to teachers and researchers, namely, knowledge of strategic thinking individually, knowledge of the genre of thought, knowledge of additional issues with the tendency of thinking (habits of mind) and knowledge of metacognition.

According to [22], teachers must have certain metacognition (thinking about thinking) components to have a clear knowledge on the strategies used in teaching thinking skills.

\subsection{THEORETICAL FOUNDATION OF THE RESEARCH}

There are various programmes currently available for teaching thinking skills. Teachers often relied on different taxonomies which they could find, the most popular among them being Bloom's taxonomy which comprised six cognitive levels. Since having various levels in taxonomy could possibly cause confusion to the teachers, attempts had been made recently to provide a taxonomy with fewer categories, such as that carried out by [23], which was later refined by [24]. They suggested that different concepts could all be subsumed under the larger construct of higher-order thinking and explained from a low level thinking ([23] and [24]). In order to provide a simple framework for teachers with the aim to have a better understanding of the application, a framework that incorporated all critical thinking skills, processes and constructs was provided by [19] (Figure 1).

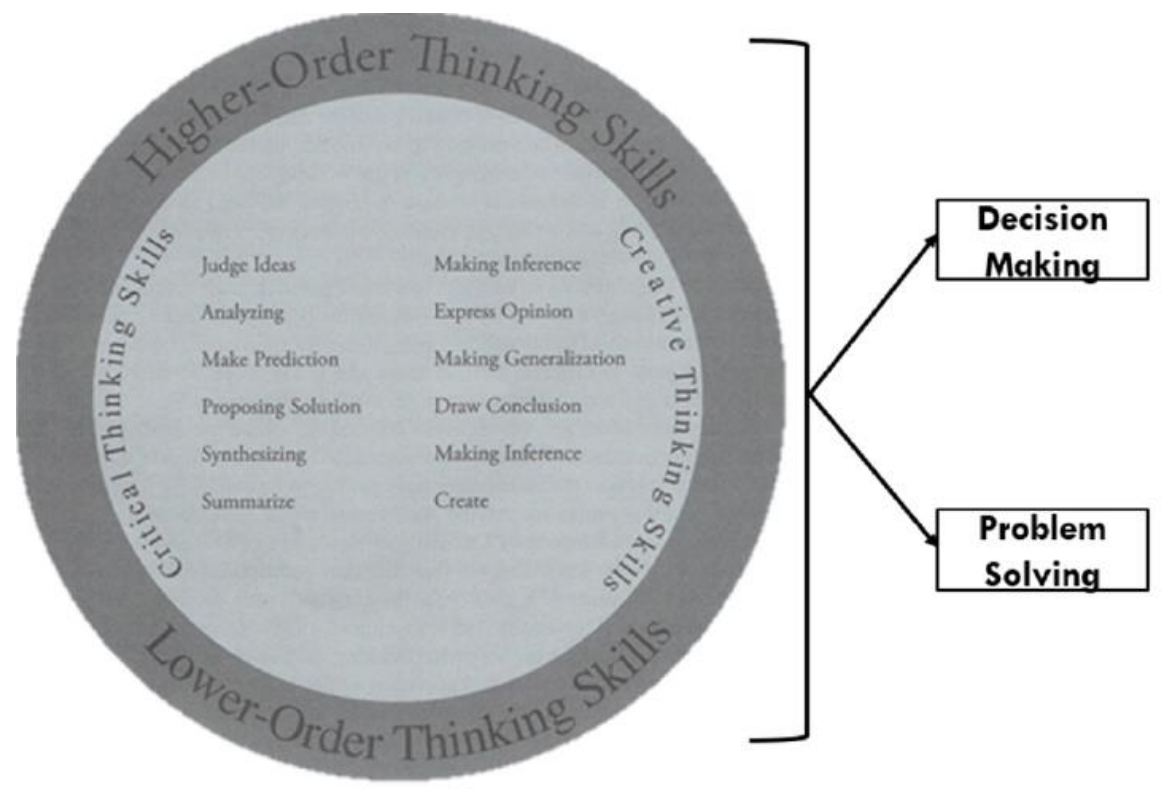

Figure 1 Framework of Thinking Skills.

The framework incorporates the numerous thinking skills one employs on a daily basis. [9] and [24] defined two major thinking categories, namely, critical thinking and creative thinking, which incorporated various other thinking skills. Higher order thinking skills and lower order thinking skills formed the umbrellas for these two major categories of thinking skills. The strategies of thinking skills were done by decision making and problem solving. Therefore, this study defined the terminologies used in each category of the thinking skills.

\section{Higher Order Thinking Skills}

Characterized as non-algorithm, complex, regulated, meaningful, effortful, and they provide a variety of solutions, considerations, criteria and uncertainty defined in terms of characteristics and cognitive processes to the individual [25]. 


\section{Lower Order Thinking Skills}

Defined as representing routine, mechanistic application and limited use of the mind. This process generally involved repetitive operations, such as, listing information and previously learned formulae, applying procedurel rules and other routinized or algorithmic mental activities ([9] and [19]).

\section{Critical Thinking Skills}

Defined as efficiency and capability to use the mind to assess the reasonableness or fairness of an idea, the advantages and disadvantages of an argument and to make sound judgment by using reasons and evidences [26].

\section{Creative Thinking Skills}

Described as a process of using the mind to explore various possibilities to produce something new, original, innovative and valuable, whether it is concrete, abstract, or ideas [26] and [27].

\subsection{METHODOLOGY}

\section{Research Design}

The purpose of this study was to determine the level of Mathematics teacher' knowledge and practices in teaching thinking skills. The results of this study were obtained by the method and design of the study, while the design of the study was determined by the objectives of the study [28]. Therefore, this study used a quantitative method of data collection through a questionnaire involving Mathematics teachers in primary and secondary schools.

\section{Research Instrument and Participants}

The instruments used were taken and adapted from the inventory study of [4] as they were found appropriate within the scope of this study. These instruments were tested for their reliability in the previous studies, where the reliability coefficient on teachers' knowledge was 0.83. [4]. The data obtained from this study was analyzed using statistical inference such as Mann Whitney U test, and descriptive statistical parameters, namely, mean and standard deviation. Specifically, this study involved a total of 199 Mathematics teachers from 25 primary and secondary schools in four districts in Johor, namely, Pontian, Kulai, Segamat, and Johor Bahru, selected by stratified random sampling.

\subsection{RESULTS AND DISCUSSION}

Descriptive analysis was also carried out to identify the level of teachers'knowledge on thinking skills. The results are shown in Table 1.

Table 1 Distribution of scores on levels of knowledge

\begin{tabular}{cccc}
\hline Score & Frequency & Percentage (\%) & Level of Knowledge \\
\hline $0-6$ & 66 & 33.2 & weak \\
\hline $7-8$ & 46 & 23.1 & fair \\
\hline $9-10$ & 53 & 26.6 & satisfactory \\
\hline $11-12$ & 29 & 14.6 & good \\
\hline $13-14$ & 5 & 2.5 & excellent \\
\hline
\end{tabular}

Based on the above analysis, it was shown that, most of the questions regarding teachers' knowledge on teaching thinking skills could not be answered by the teachers correctly. Test assessments on levels of teachers' knowledge indicated a mean score of 2.3 with the score range between 0 to 14 , while the standard deviation was 1.15 . In general, almost half of the teachers (49.7\%) had a fair and satisfactory knowledge, while a low percentage (17.1\%) of them had a good and excellent knowledge of thinking skills about. Teachers with weak knowledge of thinking skills formed the highest percentage (33.2\%), with the score range between 0 to 6 .

The results of this quantitative study identified the weaknessess in thinking skills among Mathematics teachers, especially terminology of critical and creative thinking skills. Most of the teachers who obtained the lowest score were still confused with the meaning of thinking skills, such as, critical and creative thinking skills. These results did not reflect a good sign to carry out the agenda and process of teaching thinking skills to students under the school curriculum. In addition, the delivery of thinking skills in teaching was found to be still at a level less impactful on stimulating students' thinking skills due to misconceptions on the terminology of thinking skills among Mathematics teachers. 
Table 2 Inferentials statisticals of Teachers' knowledge on teaching thinking skills

\begin{tabular}{|c|c|c|c|c|}
\hline $\begin{array}{c}\text { Group 1 } \\
(n=89)\end{array}$ & $\begin{array}{c}\text { Group 2 } \\
(n=110)\end{array}$ & $\begin{array}{c}\text { Mann- } \\
\text { Whitney U }\end{array}$ & $\mathbf{z}$ & p value \\
\cline { 1 - 2 } Mean Rank & Mean Rank & 3595.000 & -3.24 & $<0.001^{*}$ \\
\hline 85.39 & 111.82 & \\
\hline
\end{tabular}

Notes: group $1=$ primary schools teachers, group $2=$ secondary schools teachers.

Mann-Whitney U test was conducted to see whether there were differences between secondary school Mathematics teachers $(\mathrm{n}=$ $110)$ and primary schools Mathematics teachers $(n=89)$ on the teaching of thinking skills. The test results $(z=-3.24, p=.001)$ were significant at the level of $\mathrm{p}<.05$. The inferential analysis for Group 2 (secondary school Mathematics teachers) was higher (111.82), compared to that of Group 1 (primary school Mathematics teachers). The results showed that, secondary schools Mathematics teachers had a much better knowledge of teaching thinking skills compared to their peers in primary schools as portrayed in Table 2 .

This happened because, the thinking skills among secondary school Mathematics teachers were found to be better, compared to primary school teachers. The t-test results also indicated that, primary school Mathematics teachers faced problems mastering good thinking skills. Besides, it seemed that, even those who had a good understanding about teaching thinking skills found it more difficult to deliver the lessons in class and they lacked knowledge on thinking skills terminology.

\subsection{CONCLUSION}

The results of the assessments carried out in this study indicated that, the task of teaching thinking skills was not well performed, based on the mean score obtained. These results concurred with those in the study by [4]. According to [4] and [29], problems faced by the teachers in dealing with teaching thinking skills were related to their lack of knowledge and skills about the subject. In addition, most teachers had yet to gain the mastery of the concept of thinking skills and were weak in pedagogical knowledge to be implemented in the classroom ([31], [30] and [15]). Therefore, teachers must take initiatives to make improvements in their teaching and learning of Mathematics, with a particular focus on assisting the students to overcome their weaknesses in thinking skills.

Mann-Whitney test was carried out to analyze the teachers' knowledge in terms of possible significant differences which might exist between their practices and their teaching thinking skills. The results obtained indicated that, secondary school Mathematics teachers achieved mean ranking higher than their peers in primary schools. This finding was consistent with the those in the study conducted by [32], which found that, teachers in primary schools were more prepared in terms of knowledge, skills and attitudes in the field of pedagogy, compared to thinking skills, in their teaching. In addition, the teachers were found to be confused over the definition of thinking skills [33] and they had difficulty in distinguishing the levels of thinking ([16] and [34]). The lack of knowledge on thinking skills led to their inability to assess students' thinking skills.

Thus, to solve the problem of teaching thinking skills among teachers, researchers believe that it is necessary to design and develop teaching modules clearer thinking skills and proper should be extended by mathematics teachers. Therefore, it can be highlighted that, to attain the goal of having students adept at thinking skills, they should to be taught by teachers who have a high efficacy on teaching thinking skills. Since the study showed that, teachers' sense of responsibility was related to their level of knowledge, efforts must be taken to ensure that their related area of interest would be exposed formally to the theory and practice of thinking skills with they themselves being well trained in their applications.

\section{References}

Ali, S. N. (2012). Malaysian Polytechnic Lecturers' Teaching Practices with ICT Utilization to Promote Higher-Order Thinking Skills (Doctor of Philosophy Thesis). IOWA State University.

Ball, A. L., \& Garton, B. L. (2005). Modeling Higher Order Thinking: The Alignment Between Objective, Classroom Discourse and Assessments. Journal of Agricultural Education, 46(2), 58-69.

Barak, M., \& Shakhman, L. (2008). Fostering Higher-Order Thinking in Science Class: Teachers'reflections. Teachers and Teaching: Theory and Practice, 14(3), 191- 208.

Bakar, A., Shamsudin, F., Nazir, F. (2015). Teaching and Learning $21^{\text {st }}$ Century. Selangor: Sasbadi.

Beyer, B. K. (1994). Improving Thinking Skills: Defining the Problem. The Phi Delta Kappan, 65(7), 486-490.

Choy, S. C., \& Cheah, P. K. (2009). Teacher Perceptions of Crtical Thinking Among Students and Its Influence on Higher Education. International Journal of Teaching and Learning in Higher Education, 20(2), 198 -206.

Chua Yan Piaw. (2006). Kaedah Penyelidikan. Kuala Lumpur: McGraw-Hill (Malaysia) Sdn Bhd.

De Bono, E. (1976). Teaching Thinking. London: Temple Smith.

Joshi, M., \& Chugh, R. (2009). New Paradigms in the Teaching and Learning of Accounting: Use of Educational Blogs for Reflective Thinking. International Journal of Education and Development using Information and Communication Technology, 5(3), 6-18.

Marzano, R. J. (1993). How Classroom Teachers Approach the Teaching of Thinking. Theory into Practice, 32(3), 154-160.

McGregor, D. (2007). Developing Thinking; Developing Learning. United Kingdom: McGraw-Hill Education.

Mayer, R. E. (1983). Thinking, Problem Solving, Cognition. San Francisco: Freeman.

Maimunah, S. S. Z. (2004). Hala Tuju Pengajaran dan Pembelajaran Sains dan Matematik dalam Bahasa Inggeris. Diges Pendidik, Jilid 4, Bil.1/2004 1-12.

Ministry of Education. (2012). Pelan Pembangunan Pendidikan Malaysia 2013-2025. Putrajaya: Kementerian Pelajaran Malaysia.

Ministry of Education. (2012). Buku Panduan Program i-THINK. Putrajaya: Bahagian Pembangunan Kurikulum, Kementerian Pelajaran Malaysia.

Mahyudin, R., Pihie, Z. A. L., Elias, H., Konting, M. M. (2004). The Incorporation of Thinking Skills in the School Curriculum. Kajian Malaysia, 22(2), 23-33.

Mayer, R. E. (1983). Thinking, Problem Solving, Cognition. San Francisco: Freeman.

Noraini Idris. (2005). Pedagogi dalam Pendidikan Matematik, Selangor: Utusan Publications.

Onosko, J. J, \& Newmann, F. M. (1994). Creating More Thoughtful Learning Environment. in Mangieri, J. \& Blocks, C. C. (Eds.). Creating Powerful Thinking In Teachers And Students: Diverse Perspectives. Forth Worth: Harcourt Brace College Publishers. 
Othman, N., \& Mohamad, K. A. (2014). Thinking Skill Education and Transformational Progress in Malaysia. International Education Studies, 7(4), $27-32$. Rajendran Nagappan. (1998). Teaching Higher-Order Thinking Skills in Language Classrooms: The Need for Transformation of Teaching Practice (Unpublished Doctoral Dissertation). Michigan State University, East Lansing, USA.

Rajendran, N. S. (2001). Teaching higher-order thinking skills in Malaysia. Journal of Southeast Asian Education, 2(1), 42-65.

Rajendran, N. S. (2013). Teaching \& Acquiring Higher-Order Thinking Skills: Theory \& Practice. Penerbit Universiti Pendidikan Sultan Idris.

Rajendran, N.(2000) Language Teaching and the Enhancement of Higher-Order Thinking Skills. Paper presented at the Southeast Asian Ministers of Education Organization Regional Language Centre's 35th International Seminar.

Resnick. L. (1987). Education and Learning to Think. Washington, DC: National Academy.

Rosnani, H. and Suhailah, H. (2003). The Teaching of Thinking in Malaysia. Kuala Lumpur: International Islamic University Malaysia.

Saavedra, A. R. and Opfer, V. D. (2012). Learning 21st-century Skills Requires 21st-century Teaching. Kappanmagazine.Org, 94(2), 8-13.

Som Hj.Nor \& Mohd Dahalan Mohd Ramli. (1998). Kemahiran Berfikir Secara Kritis dan Kreatif (KBKK). Petaling Jaya: Longman. (1998).

Sukiman, Noor, \& Uzi. (2012). Pengajaran Kemahiran Berfikir: Persepsi dan Amalan Guru Matematik Semasa Pengajaran dan Pembelajaran di Bilik Darjah. Jurnal Pendidikan Sains \& Matematik Malaysia, 2(1), 18-36.

Swartz, R. J.and Perkins, D. N. (1990). Teaching Thinking: Issues Approaches. CA: Critical Thinking Press \& Software.

Toy, B. Y., \& Ok, A. (2012). Incorporating Critical Thinking in the Pedagogical Content of a Teacher Education Programme: Does It Make A Difference?. European Journal of Teacher Education, 35(1), 39-56.

Zohar, A. (2006).The Nature and Development of Teachers' Metastrategic Knowledge in the Context of Teaching Higher-Order Thinking. Journal of the Learning Sciences, 15(3), 331-377.

Zohar, A. (2013). Challenges in Wide Scale Implementation Efforts to Foster Higher Order Thinking (HOT) in Science Education Across A Whole Wide System. Thinking Skills and Creativity, 10, 233-249.

Zohar, A., \& Schwartzer, N. (2005). Assessing Teachers' Pedagogical Knowledge in the Context of Teaching Higher-Order Thinking. International Journal of Science Education, 27(13), 1595-1620. 